[CONTribution From the Buread of Standards, U. S. Department OF COMmerce.]

\title{
THE DETERMINATION OF ZIRCONIUM BY THE PHOSPHATE METHOD.
}

By G. E. F. LUNDELI AND H. B. KNowles. ${ }^{1}$

Received September 7, 1919.

Contants.-I. Introduction. II. General Principles. III. Historical. IV. Precipitation of Zirconium Phosphate: 1. Permissible Acidity; 2. Excess of Precipitant Required; 3. Effect of Hydrogen Peroxide; 4. Precipitation Temperature. V. Washing the Precipitate. VI. Ignition of the Precipitate. VII. Procedure Recommended. VIII. Confirmatory Experiments. IX. Separation from Other Elements: I. Iron, Aluminum and Chromium; 2. Titanium; 3. Cerium; 4. Thorium. X. Summary.

\section{Introduction.}

The determination of zirconium in ores and metallurgical products has aroused considerable interest during the past year. The method most often proposed has been the phosphate method originally devised by Hillebrand for the determination of the small amounts of zirconium usually found in ordinary rocks. It is the purpose of this paper to point out the danger involved in applying this method to the determination of large amounts of zirconium, and to give the modifications of the method which have been found to increase its accuracy.

\section{General Principles.}

The phosphate method consists essentially in precipitating zirconium from weak sulfuric acid solution by means of alkali phosphate. If titanium is present, hydrogen peroxide is added to keep it in solution. Water is usually specified by word ${ }^{2}$ or by inference ${ }^{3}$ as the washing medium, although acid washes have been recommended. ${ }^{4}$ The washed precipitate is ignited to constant weight and various factors for its zirconium content have been given: $38.38^{1}, 36.00^{2}, 38.283 \%$. The zirconium factor for $\mathrm{ZrP}_{2} \mathrm{O}_{7}$ is $34.23 \%$ while the factor for the compound ${ }_{5} \mathrm{ZrO}_{2.4} \mathrm{P}_{2} \mathrm{O}_{5}$ mentioned by Hillebrand and described in Gmelin-Kraut ${ }^{5}$ is $38.35 \%$.

It is evident that the use of any of these factors will not lead to serious errors on precipitates weighing two or three mg. In case of large precipitates the indiscriminate use of these factors cannot but lead to serious errors.

It was in the hope of discovering whether zirconium could be quantitatively separated, from ordinary contaminants, as a precipitate which would yield a residue of definite composition upon ignition, that the following work was undertaken:

1 Published by permission of the Director of the Bureau of Standards.

2 Johnson, Chem. Met. Eng., 20, 588 (1919).

${ }^{3}$ Nicolardot and Reglade, Compt. rend., 168, 349 (1919).

- Ferguson, Eng. Mining J., 106, 793 (1918).

${ }^{5}$ Gmelin-Kraut, I886, p. 703. 


\section{Historical.}

The phosphate method was first used by Hillebrand and described by him in U. S. Geological Survey, Bulletin 148 on "The Analysis of Silicate and Carbonate Rocks." The author recommended the method for the determination of the small amounts of zirconium usually found in rocks (from 0.02 to $0.2 \%$ ), and the following statements were made: "For the small amounts usually met with it is safe to assume that the ignited phosphate contains $50 \%$ of $\mathrm{ZrO}_{2}$ ( $5 \mathrm{r} .8$ by theory). If the amount is rather large, it may be safer to fuse with sodium carbonate, leach, ignite, fuse with pyrosulfate, reprecipitate by ammonia, and weigh as $\mathrm{ZrO}_{2}$." This method has been widely quoted, with the frequent omission, however, of the qualifying sentences given above. As a consequence, several methods for the determination of the larger amounts of zirconium in ores and metallurgical products have recently been published which feature the phosphate method and which specify the use of a zirconium factor based on Hillebrand's recommendation for the ignited phosphate obtained from the very small amounts of zirconium in ordinary rocks.

Steiger $^{1}$ in a brief note dealing with some tests of the method draws the following conclusions: I. Solutions containing at least $3 \%$ and perhaps as much as $5 \%$ (by weight) of free sulfuric acid may be employed in the phosphate precipitation. 2. The results indicate that basic phosphates are obtained in feebly acid solutions while an increase of acidity tends to give the normal phosphate. 3. Sufficiently accurate results can be obtained in determining the small amounts of zirconium in the average rocks by assuming that the ignited phosphate has the formula $\mathrm{ZrP}_{2} \mathrm{O}_{7}$ and that it contains $46.32 \%$ of $\mathrm{ZrO}_{2}$. Steiger's data, however, demonstrate conclusively that the composition of the ignited phosphate is extremely variable.

More recently, Nicolardot and Reglade ${ }^{2}$ have shown that complete precipitation of zirconium as phosphate may be obtained in a $20 \%$ (by weight) sulfuric acid, provided a good excess of the precipitant, ammonium phosphate, be used. They state that for an ignited phosphate obtained from a neutral solution the $\mathrm{ZrO}_{2}$ factor $0.487 \mathrm{O}$ is indicated. For a $20 \%$ acidity, however, their results indicate 0.493 as the $\mathrm{ZrO}_{2}$ factor.

\section{Precipitation of Zirconium Phosphate.}

Factors which must be considered in the precipitation of zirconium as phosphate are (I) permissible acidity; (2) excess of precipitant required; (3) effect of hydrogen peroxide; (4) precipitation temperature. The results of an investigation of the effect of these variables, which was

' J. Wash. Acad. Sci., 8,637 (1918).

:Compt. rend., Loc, cit. 
carried on at this Bureau before the publication of the article by Nicolardot and Reglade ${ }^{1}$ are summarized below.

I. Permissible Acidity.-Table I gives a summary of the work dealing with the effect of variations in acidity.

TABLe I.-EFFEct OF Variations in Acidity.

$\mathrm{ZrO}_{2}$ Taken $0.02 \mathrm{I} 6 \mathrm{~g}$. Total volume, $300 \mathrm{cc}$.

\begin{tabular}{|c|c|c|c|c|c|}
\hline Expt. & $\begin{array}{c}\mathrm{H}_{2} \mathrm{SO}_{4} \\
(\mathrm{Sp} . . \mathrm{gr} .1 .84 .) \\
\% \text { by vol. }\end{array}$ & $\begin{array}{c}\mathrm{P}_{2} \mathrm{O}_{6} \text { added } \\
\times \times \text { theory. } \\
(\mathrm{Zr}: 2 \mathrm{P} .) \\
\mathrm{G} .\end{array}$ & $\begin{array}{c}\text { Ppt. } \\
\text { obtained. } \\
\text { G. }\end{array}$ & $\begin{array}{c}\mathrm{ZrO}_{2} \text { found } \\
\text { calculated } \\
\text { on basis } \\
\mathrm{ZrP}_{2} \mathrm{O}_{7} .\end{array}$ & $\begin{array}{c}\text { Error. } \\
\mathrm{G} . \\
\mathrm{ZrO}_{2} .\end{array}$ \\
\hline г....... & 0.5 & IO & $0.045 \mathrm{I}$ & $0.0209^{2}$ & -0.0007 \\
\hline $2 \ldots \ldots \ldots$ & 0.5 & IO & 0.0455 & $0.02 I^{2}$ & -0.0005 \\
\hline $3 \ldots \ldots \ldots$ & I.O & Io & $0.046 \mathrm{I}$ & 0.0214 & -0.0002 \\
\hline $4 \ldots \ldots \ldots$ & I.O & 10 & 0.0466 & 0.0216 & -0.0000 \\
\hline $5 \ldots \ldots \ldots$ & r.o & 100 & 0.0462 & 0.0214 & -0.0002 \\
\hline 6. & 5.0 & Io & 0.0463 & 0.0214 & -0.0002 \\
\hline $7 \ldots \ldots \ldots$ & 5.0 & IO & 0.0460 & 0.0213 & -0.0003 \\
\hline 8. & 5.0 & 100 & 0.0460 & 0.0213 & -0.0003 \\
\hline $9 \ldots$ & 10.0 & IO & 0.0439 & 0.0203 & -0.0013 \\
\hline ro $\ldots \ldots \ldots$ & 10.0 & Io & 0.0442 & 0.0205 & -0.0011 \\
\hline
\end{tabular}

The data show that with moderate excess of the precipitant (Io times the theoretical requirement), $5 \%$ of sulfuric acid by volume is the maximum allowable excess acid in a cold precipitation. This bears out the prediction of Steiger. ${ }^{1}$ Nicolardot and Reglade ${ }^{1}$ working with tepid solutions and a much greater excess of the precipitant found that precipitation was complete in a solution containing $20 \%$ by weight of sulfuric acid. This observation has been confirmed at this Bureau.

The data also indicate that with acidities of $0.5 \%$ and lower, basic zirconium phosphates are formed, an observation which was also made by Steiger.

2. Excess Precipitant Required.-Table II gives the data obtained by carrying out the precipitations with various amounts of the precipitant.

TABLE II.-EFFECT OF Various Amounts OF PRECIPITANT.

$\mathrm{ZrO}_{2}$ Taken $0.0216 \mathrm{~g}$. Total Volume, $300 \mathrm{cc}$.

\begin{tabular}{|c|c|c|c|c|c|}
\hline Expt. & $\begin{array}{c}\mathrm{H}_{2} \mathrm{SO}_{4} \\
\left(\mathrm{Sp}_{\dot{\gamma}}^{\mathrm{gt} .} 1.84 .\right) \\
\% \text { by vol. }\end{array}$ & $\begin{array}{c}\mathrm{P}_{2} \mathrm{O}_{5} \text { added } \\
\times \text { theory. } \\
(\mathrm{ZT}: 2 \mathrm{P} .) \\
\mathrm{G} .\end{array}$ & $\begin{array}{l}\text { Ppt. } \\
\text { obtained. } \\
\text { G. }\end{array}$ & $\begin{array}{c}\mathrm{ZrO}_{2} \text { found } \\
\text { calculated } \\
\text { on basis } \\
\mathrm{ZrP}_{2} \mathrm{O}_{7}\end{array}$ & $\begin{array}{c}\text { Error. } \\
\mathrm{G} . \\
\mathrm{ZrO}_{2} .\end{array}$ \\
\hline I. . & $\ldots$ & 2 & 0.0379 & 0.0176 & -0.0040 \\
\hline 2. & . . $\quad I$ & 5 & 0.0453 & 0.0210 & -0.0006 \\
\hline 3. & $\ldots \quad I$ & xo & $0.046 \mathrm{r}$ & 0.0214 & -0.0002 \\
\hline 4. & $\ldots$ & 100 & 0.0462 & 0.0214 & -0.0002 \\
\hline $5 \ldots$ & $\ldots 5$ & 2 & 0.0380 & 0.0176 & -0.0040 \\
\hline 6. & .. 5 & 5 & 0.0413 & 0.0191 & -0.0025 \\
\hline 7. & 5 & 10 & 0.0463 & 0.0214 & -0.0002 \\
\hline 8. & . . 5 & 100 & 0.0460 & 0.0213 & -0.0003 \\
\hline
\end{tabular}

Loc. cit.

${ }^{2}$ Qualitative test showed complete precipitation of zirconium. 
The above experiments show that a precipitate of normal composition cannot be obtained unless a fair excess of soluble phosphate is used, the excess varying directly with the acid concentration. Nicolardot and Reglade succeeded in getting complete precipitation in an acidity as high as $20 \%$ sulfuric by weight by using a very large excess of the precipitant.

3. Effect of Hydrogen Peroxide.--Since Hillebrand's method calls for the use of hydrogen peroxide when titanium is present, the tests given in Table III were carried out to determine whether peroxide disturbed the reaction.

Table III.-EFfect of Hydrogen Peroxide.

$\mathrm{ZrO}_{2}$ Taken, $0.0216 \mathrm{~g}$. Total Volume, $300 \mathrm{cc}$.

\begin{tabular}{|c|c|c|c|c|c|c|}
\hline Expt. & $\begin{array}{c}\mathrm{H}_{2} \mathrm{SO}_{4} \\
\left(\mathrm{Sp}_{;} \mathrm{gr}_{1}, 1.84 .\right) \\
\% \text { by vol. }\end{array}$ & $\begin{array}{l}\mathrm{P}_{2} \mathrm{O}_{5} \text { added } \\
\times \text { theory. } \\
(\mathrm{Zr}: 2 \mathrm{P},)\end{array}$ & $\begin{array}{c}3 \% \\
\mathrm{H}_{2} \mathrm{O}_{2} \\
\mathrm{Cc} .\end{array}$ & $\begin{array}{c}\begin{array}{c}\text { Ppt. } \\
\text { obtained. } \\
G .\end{array} \\
\text { G. }\end{array}$ & $\begin{array}{l}\mathrm{ZrO}_{2} \text { found } \\
\text { calculated } \\
\text { on basis } \\
\text { of } \mathrm{ZrP}_{2} \mathrm{O}_{7} \text {. }\end{array}$ & $\begin{array}{c}\text { Error. } \\
\text { G. } \\
\text { ZrO. }_{2} .\end{array}$ \\
\hline I $\ldots \ldots \ldots$ & 1.0 & Io & 10 & 0.0462 & 0.0214 & -0.0002 \\
\hline $2 \ldots \ldots$ & I. 0 & 100 & 10 & 0.0463 & 0.0214 & -0.0002 \\
\hline $3 \ldots \ldots$ & 5.0 & Io & ro & 0.0460 & 0.0213 & -0.0003 \\
\hline $4 \ldots \ldots \ldots$ & 5.0 & 100 & 10 & 0.0465 & 0.0216 & -0.0000 \\
\hline $5 \ldots \ldots \ldots$ & II. 5 & 100 & None $^{1}$ & 0.0458 & 0.0212 & -0.0004 \\
\hline
\end{tabular}

The experiments show that hydrogen peroxide has no disturbing effect on the phosphate precipitation. The last test was carried out to establish whether excessive amounts of acetanilide which might be introduced with peroxide would disturb the precipitation.

4. Precipitation Temperature.-Table IV gives data obtained in phosphate precipitations which were carried on at room temperatures and by digestion on the steam bath followed by filtration of the hot solutions.

$$
\text { TABLE IV.-EFFECT OF TEMPERATURE. }
$$

$\mathrm{ZrO}_{2}$ Taken, $0.0216 \mathrm{~g}$. Total Volume, $300 \mathrm{cc}$. $\mathrm{P}_{2} \mathrm{O}_{8}$ added, so $\times$ Theory $(\mathrm{Zr}: 2 \mathrm{P})$.

\begin{tabular}{|c|c|c|c|c|c|}
\hline Expt. & $\begin{array}{c}\mathrm{H}_{3} \mathrm{SO}_{4} \\
\left(\mathrm{Sp}_{+} \mathrm{gr} .1 .84 .\right) \\
\% \text { by vol. }\end{array}$ & $\begin{array}{l}\text { Temp. of } \\
\text { precipitation } \\
\text { and } \\
\text { filtration. }\end{array}$ & $\begin{array}{c}\text { Ppt. } \\
\text { obtained. } \\
\text { G. }\end{array}$ & $\begin{array}{c}\mathrm{ZrO}_{2} \text { found } \\
\text { calculated } \\
\text { on basis } \\
\mathrm{Z}_{\mathrm{r}} \mathrm{P}_{2} \mathrm{O}_{7} .\end{array}$ & $\begin{array}{c}\text { Error. } \\
\text { G. } \\
\mathrm{ZrO}_{2} .\end{array}$ \\
\hline I. . . . & I & Cold & $0.046 \mathrm{I}$ & 0.0214 & -0.0002 \\
\hline $2 \ldots$ & I & Hot & $0.045 x$ & 0.0209 & -0.0007 \\
\hline $3 \ldots$ & 5 & Cold & 0.0463 & 0.0214 & -0.0002 \\
\hline $4 \ldots$ & 5 & Hot & 0.0434 & 0.0201 & -0.0015 \\
\hline $5 \ldots$ & Io & Cold & 0.0439 & 0.0203 & -0.0013 \\
\hline $6 . .$. & Io & Hot & 0.0410 & 0.0190 & $\longrightarrow 0.0026$ \\
\hline
\end{tabular}

The data demonstrate that the solubility of zirconium phosphate increases markedly in hot acid solutions. Undoubtedly the solubility in hot solutions could be decreased by adding a larger excess of the precipitant. At the time these experiments were performed no particular advantage resulting from the use of hot solutions was anticipated; consequently the tests were not pursued further. Nicolardot and Reglade,

${ }^{1} 0.0059 \mathrm{~g}$. acetanilide added; total volume here $100 \mathrm{cc}$. 
however, have demonstrated that precipitation is complete in luke warm or tepid solutions of high acidity, provided adequate phosphate is used.

The experiments which are given in Tables I, II, III and IV demonstrate that complete precipitation of zirconium as phosphate of definite composition may be had in cold or tepid solution containing: (I) hydrogen peroxide, (2) sulfuric acid ranging from 2 to $20 \%$ by weight and (3) secondary ammonium phosphate in ro to Ioo times the theoretical requirement.

\section{Washing the Precipitate.}

Since water is the washing medium usually employed in the phosphate determination, qualitative tests were carried out to determine whether zirconium phosphate is soluble in water or whether it suffers hydrolysis during the washing operation. It was found that no zirconium whatever could be obtained by treating with ammonium hydroxide the water washings of zirconium phosphate precipitates. It was found, however, that very considerable amounts of phosphoric acid were present in wash waters obtained by washing with water, zirconium phosphate precipitates which had first been thoroughly washed with $5 \%$ ammonium nitrate. This observation was verified quantitatively and in Table $V$ are shown the differences noted between determinations which were varied only in washing treatment.

TABle V.-EFFect OF Washing TREatMent.

Total Weight of Solution, Ioo g. Total Volume Wash Soln., 300 cc. $\mathrm{ZrO}_{2}$ Taken, $0.02 \mathrm{r} 6 \mathrm{~g}: \mathrm{H}_{2} \mathrm{SO}_{4}, 20 \%$ by Weight. $\mathrm{P}_{2} \mathrm{O}_{5}$ added, roo $X$ Theory $\left(\mathrm{Zr}:{ }_{2} \mathrm{P}\right)$.

$\begin{array}{cl}\text { Expt. } & \begin{array}{l}\text { Wash } \\ \text { solution } \\ \text { used. }\end{array} \\ 1 \ldots \ldots & \mathrm{H}_{2} \mathrm{O} \\ 2 \ldots & \mathrm{H}_{2} \mathrm{O} \\ 3 \ldots \ldots & \mathrm{NH}_{4} \mathrm{NO}_{3} 5 \% \\ 4 \ldots . & \mathrm{NH}_{4} \mathrm{NO}_{3} \%\end{array}$

$$
\begin{gathered}
\begin{array}{c}
\text { Ppt. } \\
\text { obtained. } \\
\mathrm{G} .
\end{array} \\
0.0438^{1} \\
0.0445^{1} \\
0.048^{2} \\
0.046 \mathrm{r}^{2}
\end{gathered}
$$

$\mathrm{ZrO}_{2}$ found
calculated
on basis
$\mathrm{ZrP}_{2} \mathrm{O}_{7}$
0.0203
0.0206
0.0212
0.0214

$$
\begin{gathered}
\text { Error. } \\
\text { G. } \\
\mathrm{ZrO}_{2} . \\
-0.0013 \\
-0.0010 \\
-0.0004
\end{gathered}
$$

The data in Table $\mathrm{V}$ demonstrate that no definite composition can be ascribed to an ignited water-washed phosphate and that use of a cold $5 \%$ ammonium nitrate solution almost entirely overcomes the tendency toward hydrolysis.

\section{Ignition of Precipitate.}

No special precautions were given by Hillebrand for the ignition of the phosphate precipitate and none are necessary for the small amounts encountered in ordinary rock analysis. It was soon found, however, at this Bureau that the ignition of zirconium phosphate precipitates weighing approximately $0.02 \mathrm{~g}$. was a hard problem because of difficulty in burning off carbon and the marked tendency of the precipitate to decrepitate.

1 Washings gave negative tests for zirconium but heavy tests for $\mathrm{P}_{2} \mathrm{O}_{5}$.

2 Washings gave negative tests for zirconium and very faint tests for $\mathrm{P}_{2} \mathrm{O}_{6}$. 
Nicolardot and Reglade call attention to the decrepitation of the phosphate and they also state that the final ignited product is gray-white. A water-washed precipitate such as they obtained does exhibit a strong tendency to decrepitate and it is also difficult to burn white. In fact, we have sometimes obtained from water-washed precipitates black residues of excessive weight which resisted all ignition treatments, including ignition in oxygen. The use of a properly prepared Gooch crucible obviated all these troubles but was not adopted as a standard procedure since it does not permit of convenient examination of the final weighed product. The ammonium nitrate wash which was finally adopted leaves the paper and the precipitate in the most desirable condition for the ignition, and a pure white phosphate can be obtained provided the preliminary ignition is carried on at a low temperature. Decrepitation difficulties are less marked, but with precipitates weighing more than 0.005 g. ignitions should be cautiously carried on with crucibles partly covered, particularly at the stage when the carbon envelope is burning away. The final ignition should be done over the blast lamp or Méker burner for 15 minutes. Zirconium pyrophosphate is not hygroscopic as is shown in Table VI.

TAble VI.--Exposure of Ignited Pyrophosphate.

\begin{tabular}{|c|c|c|}
\hline \multirow[b]{2}{*}{ Jixpt. } & \multicolumn{2}{|c|}{ Wt. of $\mathrm{Zr}_{2} \mathrm{P}_{2} \mathrm{O}_{7}$} \\
\hline & $\begin{array}{l}\text { After } \\
\text { ignition. }\end{array}$ & $\begin{array}{l}\text { After } 4 \text { hours' ex- } \\
\text { posure to atmosphere. }\end{array}$ \\
\hline I .. & 0.0920 & 0.0919 \\
\hline $2 \ldots$ & 0.0463 & 0.0463 \\
\hline
\end{tabular}

\section{Procedure Recommended.}

The procedure following is a modification of that published by Nicolardot and Reglade.

A. Volume of Solution.-From $25 \mathrm{cc}$. for small amounts (0.0005 g. $\mathrm{ZrO}_{2}$ ) to $200 \mathrm{cc}$. for larger amounts (o.I g.).

B. Acidity.-20\% sulfuric acid by weight.

C. Hydrogen Peroxide.-Sufficient to keep titanium dioxide peroxidized; ro cc. will do no harm.

D. Precipitant.-Secondary ammonium phosphate in excess. From 1o to too times the theoretical requirement as expressed by the ratio $\mathrm{Zr}: \mathrm{P}_{2} \mathrm{O}_{5}$ should be used. The larger excess is desirable when small amounts of zirconium dioxide are to be determined.

E. Precipitation conditions.

I. Temperature. Cold or $40-50^{\circ}$, preferably the latter.

2. Time. Two hours for amounts of zirconium dioxide in excess of $0.005 \mathrm{~g}$. Six hours or longer for smaller amounts.

$F$. Filtration.-Warm; decant as much supernatant liquid as passible to avoid clogging the filter. 
G. Washing.-With cold $5 \%$ ammonium nitrate solution.

H. Ignition.-Very careful ignition in a partially covered platinum crucible over a low flame until the filter paper carbon is destroyed, followed by blasting or its equivalent.

\section{Confirmatory Experiments.}

The results given in Table VII which were obtained by the procedure recommended, demonstrate that the method is reasonably accurate.

Table VII.-Results with Recommended Procedure.

$\mathrm{H}_{2} \mathrm{SO}_{4}, 20 \%$ by Weight; Total Volume of Solution, too cc.; $\left(\mathrm{NH}_{4}\right)_{2} \mathrm{HPO}_{4}$ Taken, I.0 g.; Wash Solution, $5 \% \mathrm{NH}_{4} \mathrm{NO}_{3}$.

\begin{tabular}{|c|c|c|c|c|c|c|}
\hline Expt. & $\underset{\mathrm{Cc} .}{\mathrm{H}_{2} \mathrm{O}_{2} .}$ & $\begin{array}{c}\mathrm{TiO}_{2} \\
\text { added. } \\
\mathrm{G} .\end{array}$ & $\begin{array}{l}\text { Zr } \\
\text { phosphate } \\
\text { weighed. } \\
\text { G. }\end{array}$ & $\begin{array}{c}\mathrm{ZrO}_{2} \text { found } \\
\text { calculated } \\
\text { on basis } \\
\mathrm{Zr}_{2} \mathrm{P}_{2} \mathrm{O}_{7} . \mathrm{G} .\end{array}$ & $\begin{array}{c}\mathrm{ZrO}_{2} \\
\text { added. } \\
\mathrm{G} .\end{array}$ & $\begin{array}{c}\text { Diff. } \\
\text { G. } \\
\mathrm{Z}_{\mathrm{rO}} .\end{array}$ \\
\hline I. & To & none & 0.0014 & 0.00065 & 0.00064 & +0.00001 \\
\hline 2. & I0 & none & 0.0023 & 0.00106 & 0.00107 & -0.00001 \\
\hline $3 \ldots \ldots$ & IO & none & 0.0040 & 0.00185 & 0.00193 & -0.00008 \\
\hline $4 \ldots \ldots$ & ro & 0.0990 & 0.0022 & 0.00102 & 0.00107 & -0.00005 \\
\hline $5 \ldots \ldots$ & none & none & $0.0453^{1}$ & 0.0210 & 0.0216 & -0.0006 \\
\hline $6 \ldots \ldots$ & none & none & 0.0458 & 0.0212 & 0.0216 & -0.0004 \\
\hline 7. & ro & none & 0.0461 & 0.0214 & 0.0216 & $\multimap 0.0002$ \\
\hline & Io & none & 0.0457 & 0.0212 & 0.0216 & $\multimap 0.0004$ \\
\hline $9 \ldots \ldots$ & none & none & 0.0458 & 0.0212 & 0.0216 & -0.0004 \\
\hline ro...... & none & none & $0.0920^{1}$ & 0.0426 & 0.0431 & -0.0005 \\
\hline
\end{tabular}

It will be noticed that the values obtained are slightly lower than theoretical amounts. This was expected on account of the slight hydrolysis during the washing of the precipitate and the difficulty in preventing losses due to decrepitation.

\section{Separation from Other Elements.}

1. Iron, Aluminum and Chromium.-Nicolardot and Reglade have shown that a perfect separation from aluminum, chromium and iron can be had by the procedure outlined.

2. Titanium.-Before the publication of the paper of Nicolardot and Reglade, tests made at this Bureau demonstrated that complete separation from titanium was possible by one precipitation in the presence of hydrogen peroxide in solutions of lower acidity than $20 \%$ by weight. A summary of the results obtained is given in Table VIII.

\section{Table VIII.-Separation hrom Titanium.}

\begin{tabular}{|c|c|c|c|c|c|c|c|}
\hline $\begin{array}{l}\text { Expt, } \\
\text { No. }\end{array}$ & 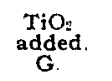 & $\begin{array}{l}\mathrm{ZrO}_{2} \\
\text { added. } \\
\mathrm{G}\end{array}$ & $\begin{array}{l}\mathrm{H}_{2} \mathrm{SO}_{4} \\
\text { resent. }\end{array}$ & $\begin{array}{c}\mathrm{ZrP}_{2} \mathrm{O}_{7} \\
\text { obtained } \\
\mathbf{G} .\end{array}$ & $\begin{array}{c}\mathrm{ZrO}_{2} \\
\text { equiva- } \\
\text { lent. } \mathrm{G} .\end{array}$ & $\begin{array}{c}\text { Error. } \\
\text { G. } \\
\mathrm{ZrO}_{2} .\end{array}$ & $\begin{array}{l}\text { Results of colorim- } \\
\text { eter tests of } \\
\text { ignited residues. }\end{array}$ \\
\hline & 0.0990 & 0.00107 & $20 \%$ by wt. & 0.0022 & 0.00102 & -0.00005 & 5 Ti-faint trace ${ }^{2}$ \\
\hline & 0.0198 & 0.0216 & I\% by vol. & $0.046 I$ & 0.0214 & -0.0002 & Ti-faint trace ${ }^{2}$ \\
\hline & o.0198 & 0.0216 & $5 \%$ by vol. & 0.0464 & 0.0215 & -0.0001 & Ti-faint trace ${ }^{2}$ \\
\hline
\end{tabular}

1 Decrepitation.

2 Less than $0.00005 \mathrm{~g}$. of $\mathrm{TiO}_{2}$. 
3. Cerium.-The data given in Table IX show that zirconium can be quantitatively separated from cerium present in either of its valences.

\begin{tabular}{|c|c|c|c|c|c|c|}
\hline Expt. & $\begin{array}{c}\mathrm{ZrO}_{2} \\
\text { added. } \\
\mathrm{G} .\end{array}$ & $\begin{array}{l}\text { Cerium oxide } \\
\text { added. } G \text {. }\end{array}$ & $\begin{array}{l}\mathrm{H}_{2} \mathrm{O}_{2} \\
\mathrm{Cc} .\end{array}$ & $\begin{array}{l}\mathrm{Z}_{\mathrm{r}} \mathrm{P}_{2} \mathrm{O}_{7} \\
\text { found. }\end{array}$ & $\begin{array}{c}\mathrm{ZrO}_{2} \\
\text { calculated } \\
\text { onl basis } \\
\mathrm{ZrP}_{2} \mathrm{O}_{7} .\end{array}$ & $\underset{\mathrm{ZrO}_{2} .}{\text { Error. }} \mathrm{G}$ \\
\hline I $\ldots \ldots$ & 0.0216 & $0.0246 \mathrm{Ce}_{2} \mathrm{O}_{3}$ & none & 0.0457 & 0.0212 & -0.0004 \\
\hline $2 \ldots \ldots$ & 0.0216 & $0.0246 \mathrm{Ce}_{2} \mathrm{O}_{3}$ & IO & 0.0453 & 0.0210 & -0.0006 \\
\hline $3 \ldots \ldots$ & 0.0216 & $0.0246 \mathrm{CeO}_{2}$ & none & 0.0449 & 0.0208 & -0.0008 \\
\hline
\end{tabular}

4. Thorium.-The data given in Table $X$ show that zirconium can be quantitatively separated from thorium by the method given.

TABLE X.-SEPARATION FROM THORIUM.

\begin{tabular}{|c|c|c|c|c|c|c|c|c|}
\hline Expt. & $\begin{array}{c}\mathrm{ZrO}_{2} \\
\text { added. } \\
\mathrm{G} .\end{array}$ & $\begin{array}{l}\mathrm{ThO}_{2} \\
\text { added. } \\
G .\end{array}$ & $\begin{array}{c}\mathrm{H}_{2} \mathrm{SO}_{4} . \\
\left(\mathrm{Sp}_{\mathrm{g}} \mathrm{gr} .\right. \\
1.84 .) \\
\mathrm{Cc} .\end{array}$ & $\begin{array}{c}\mathrm{H}_{2} \mathrm{O}_{2} \\
\mathrm{Cc}\end{array}$ & $\begin{array}{c}\left(\mathrm{NH}_{4}\right)_{2-} \\
\mathrm{HPO}_{4} \\
\text { G. }\end{array}$ & $\begin{array}{l}\mathrm{ZrP}_{2} \mathrm{O}_{7} \\
\text { found. }\end{array}$ & $\begin{array}{r}\mathrm{ZrO}_{2} \\
\text { calculated } \\
\text { on basis } \\
\mathrm{ZrP}_{2} \mathrm{P}_{7} .\end{array}$ & $\underset{\mathrm{ZrO}_{2 .}}{\text { Error. }} \mathrm{G}$. \\
\hline I..... & 0.0216 & 0.0263 & II. 5 & none & I & 0.0470 & 0.0218 & to.0002 \\
\hline $2 \ldots \ldots$ & 0.0216 & 0.0263 & II. 5 & Io & I & 0.0465 & 0.0215 & -0.0001 \\
\hline
\end{tabular}

X. Summary.

From the above experiments made at the Bureau of Standards and elsewhere, the following conclusions may be drawn:

r. Zirconium can be quantitatively precipitated as secondary zirconium phosphate in cold or tepid solutions containing from 2 to $20 \%$ by weight of sulfuric acid, provided a IO-Ioo-fold excess of the precipitant, diammonium phosphate, is used.

2. Hydrolysis, which occurs when the phosphate precipitate is washed with water, can be almost entirely avoided by the use of a cold $5 \%$ ammonium nitrate washing solution.

3. Zirconium pyrophosphate, for which the $\mathrm{ZrO}_{2}$ factor is 0.4632 , is obtained upon ignition of a secondary zirconium phosphate which had been washed with ammonium nitrate solution.

4. No definite composition can be ascribed to a compourid resulting upon ignition of a secondary zirconium phosphate which has been washed with water.

5. Zirconium can be quantitatively separated as phosphate in a: $20 \%$ by weight sulfuric acid solution from iron, aluminum, ehromium, cerium and thorium. The separation from titanium is satisfactory provided hydrogen peroxide is present.

Wasersoton, D. C. 